\title{
Histomorphometric Evaluation of Bone Regeneration Induced by Biodegradable Scaffolds as Carriers for Dental Pulp Stem Cells in a Rat Model of Calvarial "Critical Size" Defect
}

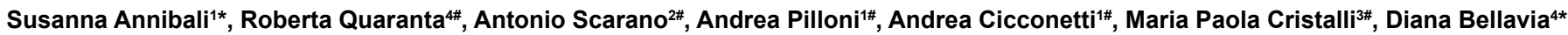 \\ and Livia Ottolenghi ${ }^{1 \#}$
}

${ }^{1}$ Department of Oral and MaxillofacialSciences, Sapienza University of Rome, Rome, Italy

${ }^{2}$ Department of Medical, Oral Sciences and Biotechnologies, University of Chieti- Pescara, Chieti, Italy

${ }^{3}$ Department of Biotechnologies and Medical Surgical Sciences, Sapienza University of Rome, Rome, Italy

${ }^{4}$ Department of Molecular Medicine, Sapienza University of Rome, Rome, Italy

\#The Authors contributed equally to this work

\begin{abstract}
Objective: The aim of this study was to test specific stem cells that could enhance bone formation in combination with specific scaffolds.

Methods: Dental Pulp Stem Cells (DPSCs) were seeded with Granular Deproteinized Bovine Bone (GDPB) or Beta-Tricalcium Phosphate (B-TCP) in a rat model of calvarial "critical size" defect. DPSCs were isolated from permanent human teeth, obtained and characterized using specific stem cells markers (Nanog and Oct-4) by real time-PCR and immunofluorescence. Cells were differentiated for 10-15 days towards the osteoblastic phenotype with $100 \mu \mathrm{M} \mathrm{L-ascorbic} \mathrm{acid,} \mathrm{added} \mathrm{every} \mathrm{day} \mathrm{in} \mathrm{culture} \mathrm{medium} \mathrm{and} 20$ vol. percentage of FBS in a-MEM medium. Osteogenic commitment was evaluated with real time-PCR by measuring the expression of specific markers (osteonectin and runx2). When a sufficient cell number was obtained, DPSCs were trypsinized, washed in culture medium and seeded onto the GDPB and B-TCP scaffold sat a density of $0.5-1 \times 10^{6}$ cells/scaffold. Two bilateral critical-size circular defects ( $5 \mathrm{~mm}$ diameter; $1 \mathrm{~mm}$ thickness) were created from the parietal bone of the 8 athymic T-cell deficient nude rats. One cranial defect for each rat was filled with the scaffold alone and the other defect with the scaffold seeded with stem cells. After 12 weeks post-surgery animals were euthanized and histomorphometric analysis was performed. Differences between groups were analyzed by one-way analysis of variance (ANOVA) followed by Fisher's Protected Least Significant Difference (PLSD) post-hoc test. A p-value $<0.05$ was considered statistically significant.
\end{abstract}

Results: GDPB group presented higher percentage of lamellar bone than that of GDPB/DPSC, ß-TCP alone had lower levels as compared to ß-TCP/DPSC. The addition of stem cells significantly increased woven bone formation in both scaffold-based implants, although still higher in GDPB based implants.

Conclusion: Our findings indicate that GDPB and B-TCP used as scaffold to induce bone regeneration may benefit from adding DPSC to tissue-engineered constructs.

Keywords: Mesenchymal stem cell; Dental pulp stem cells; Regenerative medicine; Bone formation; Histomorphometry; Biomaterials; Granular deproteinized bovine bone; Beta-tricalcium phosphate

\section{Introduction}

Improvement of successful methods for the induction of bone regeneration is a significant clinical problem in oral reconstructive surgery critical size bony defects, resulting from trauma, chronic infection, congenital defects, or surgical resection. Autologous bone grafting remains the gold standard for its osteogenic, osteoinductive and osteoconductive properties but it has significant drawbacks, included limited intraoral supply, an additional operation under general anesthesia in case of extraoral donor site, donor site discomfort and morbidity.

In the recent years the use of biomaterials has been adopted to guide and favour bone regeneration due to their capability to mimic the natural environment of the extracellular matrix [1]. To further increase the effectiveness of this methodology, the use of different scaffolds in association with stem cells with osteoblast-like activity has been introduced [2,3]. Mesenchymal stem cells (MSCs) have been proved to be effective with such developed biomaterials, since they are capable to induce new bone formation in critical-size defects of animal models after differentiation towards osteoblastic phenotype [4-7] In particular, it has been investigated the capacity of inducing bone formation of two stem cell populations, dental pulp stem cells (DPSCs) [8] and periosteal stem cells (PeSC) [9], seeded with different scaffolds in a tissue-engineered construct.

It is now known that in human dental pulp tissue there is a subset

*Corresponding authors: Susanna Annibali, Associate Professor of Oral Surgery School of Dentistry Director of Postgraduate Program in Oral Surgery, Department of Oral and Maxillo Facial Sciences Sapienza University of Rome, Italy, Tel: +39 06 49976651l; Fax: +39 06 44230811; E-mail: susanna.annibali@uniroma1.it

Diana Bellavia, Associate Professor of Pathology, Department of Molecular Medicine, Sapienza University of Rome, Italy, Tel: (+39 06) 49255674; E-mail: Diana.bellavia@uniroma1.it

Received November 17, 2015; Accepted January 08, 2016; Published January 15, 2016

Citation: Annibali S, Quaranta R, Scarano A, Pilloni A, Cicconetti A, et al. (2016) Histomorphometric Evaluation of Bone Regeneration Induced by Biodegradable Scaffolds as Carriers for Dental Pulp Stem Cells in a Rat Model of Calvarial "Critical Size" Defect. J Stem Cell Res Ther 6: 322. doi:10.4172/2157-7633.1000322

Copyright: (c) 2016 Annibali S, et al. This is an open-access article distributed under the terms of the Creative Commons Attribution License, which permits unrestricted use, distribution, and reproduction in any medium, provided the original author and source are credited. 
Citation: Annibali S, Quaranta R, Scarano A, Pilloni A, Cicconetti A, et al. (2016) Histomorphometric Evaluation of Bone Regeneration Induced by Biodegradable Scaffolds as Carriers for Dental Pulp Stem Cells in a Rat Model of Calvarial "Critical Size" Defect. J Stem Cell Res Ther 6: 322. doi:10.4172/2157-7633.1000322

Page 2 of 8

of stem cells, that present mesenchymal characteristics and could be directionally differentiated towards various lineages, like adipogenic, osteogenic chondrogenic, myogenic and neurogenic ones. DPSCs display multifactorial potential such asproliferative capacity, easy accessibility, high viability and osteogenic differentiation capacity. Furthermore their retrieval is relatively simple and non-invasive, no risks for developing immune reactions or rejection following transplantation exist and no immunosuppressive therapyis needed [8]. In association with appropriated scaffolds DPSCs represent thus an ideal stem cell population to build a tissue-engineered construct.

Among the scaffolds utilized in dentistry for bone regeneration, Granular Deproteinized Bovine Bone (GDPB) (Geistlich Bio-Oss ${ }^{\mathbb{R}}$ Collagen, Geistlich Pharma North America, Inc. 202 Carnegie Center, Princeton, NJ 08540) and Beta-Tricalcium Phosphate (ß-TCP) (SynthograftTM, Bicon Dental Implants, 501 Arborway, Boston, MA 02130 USA) are two of the most widely utilized because of their composition, structure, and degradation profile. GDPB is a bone substitute of bovine origin made by bone granules supplemented with $10 \%$ highly purified porcine collagen with a porosity (250-1000 $\mu \mathrm{m})$ and crystal size similar to human bone. B-TCP is a synthetic, biocompatible, and resorbable granular ceramic material with a pore size of $50-500 \mu \mathrm{m}$.

The combination of DPSCs with these scaffolds is therefore an ideal combination to generate a valid tissue-engineered construct, which can provide useful data on a translational perspective of clinical use in scaffold-based bone tissue engineering.

With this in mind, in a first study [10] we found that bone regeneration capacity of DPSC or PeSCin SCID BEIGE nude mice, measured as a percentage of bone volume of the total defect area, did not significantly differ from that induced by the scaffolds alone when seeded with two scaffolds commercially available [GDPB [11] and (B-TCP) [12]. Subsequently, we investigated the regeneration capacity of two previously tested biomaterials, used alone and in combination with DPSC, in nude immunodeficient rats using micro-Computed tomography (micro-CT) to evaluate Bone Mineral Density (BMD) and Positron Emission Tomography (PET) to analyze the relationship between osteoblastic and osteoclastic activities [13]. The results gave us valuable information on the positioning of the implanted scaffold and the capacity to induce bone formation measured as Bone Mineral Density (BMD) or Standard Up-take Value (SUV) of Sodium Fluoride Tracer $((18 \mathrm{~F})-\mathrm{NaF})$ incorporation. The data showed that GDPB-based implant were more precisely positioned, as compared to B-TCP. Moreover, GDPB induced higher BMD and SUV values within the cranial defect as compared to $B$-TCP, either alone or in combination with stem cells. However, the contribution of stem cells to new bone formation was unclear, since no significant trend to increase in BMD and SUV values as compared to the scaffolds grafted alone was found.

Thus, in this study we characterized bone formation induced into the graft by means of histochemical analysis. These data included the evaluation of the percentages of residual biomaterial, new bone formation and marrow spaces in cranial defects filled with GDPDand B-TCP-based implants, alone or in combination with DPSC. Moreover, qualitative observations with histomorphometry were provided, consisting in the determination of bone quality (lamellar or woven), the presence of residual biomaterial and inflammatory mediators within the defect.

\section{Materials and Methods}

\section{Animals}

Athymic T-cell deficient nude rats $(\mathrm{n}=8)$ (NIH-RNU FOXN1, Charles River Laboratories International, Inc. Wilmington, MA, USA), ranging from 12-14 weeks of age, were used in this study. The use of such specific strains of rats was decided because they do not show immune response because of the necessity of using human stem cells for bone regeneration. Rats were kept under standard conditions (12/12h dark/light cycle and access to water and food ad libitum). The guidelines for ethical conduct (D.Lgs. n.26/2014, in accordance with European Directive 2010/63/UE) were followed and all efforts were made to minimize animal pain or discomfort.

\section{Scaffolds}

GDPB and B-TCP were utilized to prepare the tissue-engineered scaffolds. The regenerative potential of Geistlich Bio-Oss ${ }^{\circledR}$ Collagen distinguishes it clearly from simple collagen sponges, because $90 \%$ of particles of Geistlich Bio-Oss ${ }^{\circledR}$ serve as a scaffold for new bone formation, and $10 \%$ collagen of porcine origin makes it malleable and easy to handle.

ß-TCP provides for an optimal environment for bone regeneration, because both micro-porosity and nano-porosity (pore size of 50-500 $\mu \mathrm{m})$ give it a greater surface area compared to other synthetic bone grafting materials, and allow for rapid vascularization and subsequent resorption. Furthermore, as a pure synthetic material, it does not have the inherent risks associated with biologically-derived bone graft materials.

\section{Cell culture: characterization and osteogenic differentiation of DPSC}

Dental pulp stem cells (DPSCs) were isolated from human impacted third molars extracted from adults (19-29 years of age) and cultured according to established protocols [14]. Briefly, the pulp tissue was gently separated from the crown and root and then digested in a solution of $3 \mathrm{mg} / \mathrm{ml}$ collagenase type I $\left(\mathrm{Gibco}^{\circledR}\right)$ and $4 \mathrm{mg} / \mathrm{ml}$ dispase $\left(\mathrm{Gibco}^{\circledR}\right)$ in a $\mathrm{Ca}^{2+}-\mathrm{Mg}^{2+}$ free phosphate-buffered saline (PBS, EuroClone $\left.{ }^{\circledR}\right)$ at $37^{\circ} \mathrm{C}$ for 1 hour, in agitation (950rpm) on a docking platform (Eppendorf Thermomixer). A single-cell suspension was obtained by passing the cells through a $70-\mu \mathrm{m}$ cell strainer (BD Falcon ${ }^{\mathrm{TM}}$ ) and then the cells were seeded into a $60 \mathrm{~mm}$ plastic tissue culture dish (BD Falcon ${ }^{\mathrm{TM}}$ ) and cultured with a-MEM medium (EuroClone ${ }^{\mathbb{R}}$ ) supplemented with $10 \%$ fetal bovine serum (FBS, Gibco ${ }^{\circledR}$ ), $2 \%$ penicillin/streptomycin $\left(\right.$ EuroClone $^{\mathbb{R}}$ ), and 1\% L-glutamine (EuroClone ${ }^{\mathbb{R}}$ ), then incubated at $37^{\circ} \mathrm{C}$ in a humid atmosphere containing $5 \% \mathrm{CO}_{2}$. On the following day, red blood cells and other non-adherent cells were removed and fresh medium was added to favour the growth of adherent stem cells. The cells were allowed to reach approximately $80 \%$ confluence and were defined as passage zero (P0) cells. Later passages were named accordingly. For passaging, the cells were washed with PBS and detached by incubating with $0.05 \%$ trypsin-EDTA $0.02 \%$ in PBS solution (EuroClone ${ }^{\circledR}$ ) for $5-10 \mathrm{~min}$ at $37^{\circ} \mathrm{C}$. Stem cells were replated in a new $100 \mathrm{~mm}$ dish with an appropriate dilution. Growth medium was replaced every 3 days over a 15-20 day period.

Primary cell lines of DPSCs were characterized using specific stem cells markers such as Nanog and Oct- 4 (POU class 5 homeobox 1 ) by western blot, immunofluorescence, and RT-PCR. The primary antibody against Oct-4 and Nanog where purchased respectively from Abcam (cat. number ab19857) and Cosmo Bio (cat. number RCAB0002P-F). 
Citation: Annibali S, Quaranta R, Scarano A, Pilloni A, Cicconetti A, et al. (2016) Histomorphometric Evaluation of Bone Regeneration Induced by Biodegradable Scaffolds as Carriers for Dental Pulp Stem Cells in a Rat Model of Calvarial "Critical Size" Defect. J Stem Cell Res Ther 6: 322. doi:10.4172/2157-7633.1000322

Page 3 of 8

\begin{tabular}{|c|c|c|c|c|}
\hline Genes & $\begin{array}{l}\text { Forward primer }(F) \\
\text { Reverse primer (R) }\end{array}$ & $\begin{array}{c}\text { Gene Bank } \\
\text { accession no. }\end{array}$ & $\begin{array}{l}\text { Size of PCR } \\
\text { product (bp) }\end{array}$ & $\begin{array}{c}\text { Annealing } \\
\text { temperature }\left({ }^{\circ} \mathrm{C}\right)\end{array}$ \\
\hline NANOG & $\begin{array}{l}\text { F: CCTCTTAAATTTTTTCCTCCTCTTC } \\
\text { R: AAGTGGGTTGTTTGCCTTTG }\end{array}$ & NM_024865 & 271 & 54 \\
\hline $\begin{array}{c}\text { Oct-4 (Pou5f1; POU class } \\
5 \text { homeobox } 1)\end{array}$ & $\begin{array}{c}\text { F: TGCCGTGAAACTGAAGAAG } \\
\text { R: TTTCTGCAGAGCTTTGATGTTC }\end{array}$ & NM_203289 & 72 & 53 \\
\hline Osteonectin & $\begin{array}{l}\text { F: TCTTCCCTGTACACTGGCAGTTC } \\
\text { R: AGCTCGGTGTGGGAGAGGTA }\end{array}$ & NM_003118 & 73 & 55 \\
\hline $\begin{array}{l}\text { Runx2 (runt-related } \\
\text { transcription factor 2) }\end{array}$ & $\begin{array}{l}\text { F: CAGACCAGCAGCACTCCATA } \\
\text { R: CAGCGTCAACACCATCATTC }\end{array}$ & NM_004348 & 178 & 57 \\
\hline$\beta$-actin & $\begin{array}{l}\text { F: CTACAATGAGCTGCGTGTGG } \\
\text { R: CGGTGAGGATCTTCATGAGG }\end{array}$ & NM_001101 & 314 & 60 \\
\hline
\end{tabular}

Table 1: RT-PCR primers used in this study.

For RT-PCR, the sense and antisense primers used are adapted from [15] and listed in (Table 1). The expression of CD146 was evaluated by flow cytometry (FACS Calibur, BD Biosciences) using an a-CD146 antibody (BD Pharmingen ${ }^{\mathrm{TM}}$, cat. number 550315) [16]. The data were analyzed with Cell Quest software (BD Biosciences) and the forward and side scatter profile gated out debris and dead cells.

According to established protocols [14], differentiated cells towards osteoblastic phenotype were obtained by treatment with $100 \mu \mathrm{ML}$ ascorbic acid (Sigma), added every day in the culture medium, and increasing the FBS from 10 to $20 \%$ in the a-MEM medium. The cells were treated 10-15 days before using them to seed the scaffolds. The osteogenic commitment was identified by the expression of specific markers, such as osteonectin, and runx2 (runt-related transcription factor 2) by RT-PCR. The sense and antisense primers used are adapted from $[15,16]$ and listed in Table 1.

\section{Isolation of dental stem cells and in vitro osteogenic differentiation.}

The majority of cells displayed a fibroblast-like, spindle-shaped morphology as shown in (Figure 1a), and no changes were observed throughout the passages. In order to evaluate the undifferentiated state of DPSCs isolated, we analyzed the expression of CD146, a known cell surface marker identified on mesenchymal stem cells [17], by flow cytometry analysis. As reported in (Figure 1b), 91.45\% of the cells are positive to CD146 respect to the control. To better characterized the cells, we analyzed the expression of other markers related staminality, like nanog and oct-4, by western blot (Figure 1c), RT-PCR (Figure 1d) and immunofluorescence analyses (Figure 1e).

In order to differentiate the staminal cells towards osteogenic phenotype we treated them with $100 \mu \mathrm{M} \mathrm{L}$-ascorbic acid and we added a $20 \%$ of FBS in the $\alpha$-MEM medium, since is well-known that FBS exerts a differentiation activity favoring osteoblastic differentiation, when used in high percentage [18]. mRNA isolated from DPSCs after the treatment was used for RT-PCR analysis to evaluated the expression of osteogenic markers, like runx2 and osteonectin, as shown in (Figure 1f). The DPSCs triggered towards osteogenic differentiation were used to seed the scaffolds.

\section{Scaffold preparation}

When a sufficient cell number was obtained, DPSCs were seeded onto the scaffolds. For each sample, a little block, approximately $5 \times 5 \times 1$ $\mathrm{mm}$, of granular deproteinized bovine bone (GDPB, Geistlich Bio-Oss Collagen $^{\circledR}$ ) was posed in a 24 -well plates, while for beta-tricalcium phosphate ( $\beta$-TCP, Synthograft $\left.{ }^{\mathrm{TM}}\right)$ an amount of granulate was distributed in each well of a 96-well plate. Both of them were pre-wetted before adding the cells through an incubation in culture medium at $37^{\circ} \mathrm{C}$ for $1 \mathrm{~h}$. The differentiated cells, after the treatment with 20 vol. $\%$ of FBS and $100 \mu \mathrm{M} \mathrm{L}$-ascorbic acid, were trypsinized, then washed in culture medium and seeded on the scaffolds at a density of $0,5-1 \times 10^{6}$ cells/scaffold. The amount of cells needed were centrifuged and then resuspended in a little amount of culture medium in order to gently plate them on the scaffold with a micropipette. For the GDPB alone, the scaffold was transfer in a new well before adding the cells and, after 1 hour, $1 \mathrm{ml}$ of medium was added to the well with GDPB plus DPSC. The in vitro cell constructs were cultured in osteogenic inducing medium for 2 days in a humidified atmosphere at $37^{\circ} \mathrm{C}$ containing $5 \%$ $\mathrm{CO}_{2}$.

\section{In vivo cranial defect}

Two bilateral critical-size circular defects ( $5 \mathrm{~mm}$ diameter, 1-mm thickness) were created on either side of the sagittal suture line in the parietal bone soft the rat skull, using a hand drill and trephine, under sterile saline to protect the brain from heating. During the procedure, care was taken to avoid damages to the sagittal suture and to the dura mater. Surgery was performed under general anesthesiaby $0.3 \mathrm{cc}-0.5$ cc intraperitoneal injection of Ketamine $(100 \mathrm{mg} / \mathrm{ml})+$ Xylazine $(20$ $\mathrm{mg} / \mathrm{ml})+$ Acepromazine $(10 \mathrm{mg} / \mathrm{ml})$ mixed in 2:1 sterile saline. Ketoprofen $(5 \mathrm{mg} / \mathrm{kg})$ was used preoperative for preemptive analgesia and postoperative every 12-24 hrs. In addition, the animals were given one intraperitoneal injection of $70 \mathrm{mg}$ of streptomycin to prevent infection.

\section{Experimental groups}

The animals were divided into two experimental groups $(\mathrm{n}=4$ animals/group): (1) scaffolds seeded with stem cells $\left(0.5-1 \times 10^{6}\right.$ DPSC); (2) scaffold without cells. In each rat, one cranial defect was filled with the scaffold alone and the other defect with the scaffold seeded with stem cells. Thus, four experimental groups were generated by combining scaffolds and stem cells: $B$-TCP $(ß)$; $\beta$-TCP/DPSC(ß/C); GDPB (G) and GDPB/DPSC(G/C). After 12 weeks post-surgery animals were euthanized with an anaesthetic overdose by intraperitoneal injection of $3 \%$ pentobarbital sodium and histological analysis was performed.

\section{Histological analysis}

The specimens were washed in saline solution and immediately fixed in $4 \%$ para-formaldehyde and $0.1 \%$ glutaraldehyde in $0.15 \mathrm{M}$ cacodylate buffer at $4^{\circ} \mathrm{C}$ and $\mathrm{pH} 7.4$, to be processed for histology.

The samples were fixate in PFA for three days. The specimens were processed to obtain thin ground sections with the Precise 1 Automated System (Assing, Rome, Italy). The specimens were 
Citation: Annibali S, Quaranta R, Scarano A, Pilloni A, Cicconetti A, et al. (2016) Histomorphometric Evaluation of Bone Regeneration Induced by Biodegradable Scaffolds as Carriers for Dental Pulp Stem Cells in a Rat Model of Calvarial "Critical Size" Defect. J Stem Cell Res Ther 6: 322. doi:10.4172/2157-7633.1000322

A
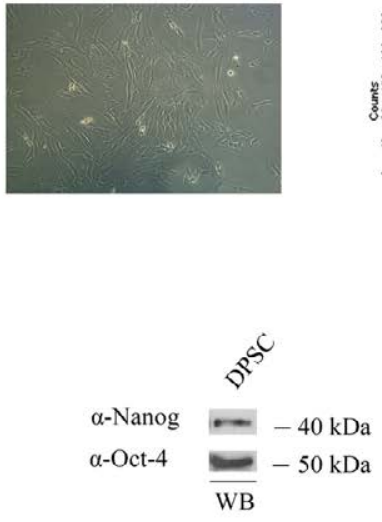

$\mathrm{E}$

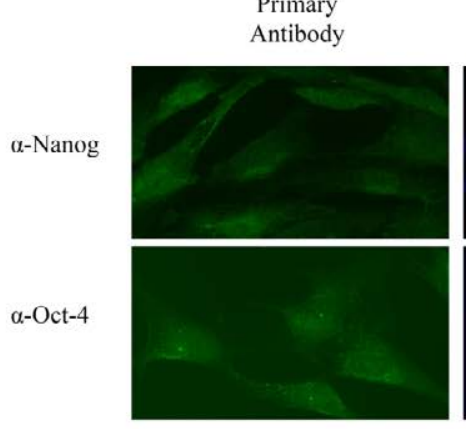

B
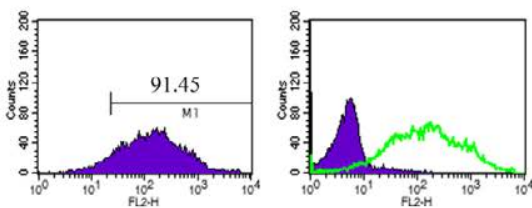

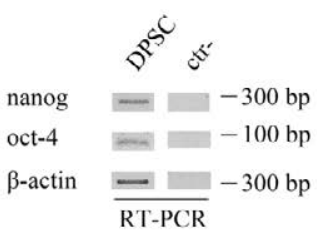

$\overline{\text { RT-PCR }}$

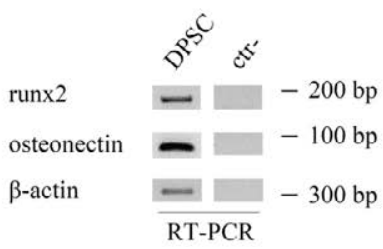

Figure 1: a) bright-field image showing the morphology of DPSCs isolated from permanent human teeth dental pulp; b) flow cytometry analysis of cell-surface markers in DPSCs. Cells were labelled with CD146 or immunoglobulin isotype antibodies: the graph on the left shows the percentage of positive cells for CD146, on the right is evidenced the expression of CD146 (green line) respect to control; c)Nanog and Oct-4 expression in DPSCs was determined in whole-cell extract by immunoblot analysis using specific antibodies; d) expression of transcript for nanog and oct-4 genes by RT-PCR. Internal control: $\beta$-actin. Negative control: water; e) immunofluorescence staining for Nanog (green) and Oct-4 (green) in DPSCs. Nuclei were labelled with DAPI (blue). Magnification:×40; f) expression of transcript for runx2 and osteonectin genes by RT-PCR. Internal control: $\beta$-actin. Negative control: water. DPSC: dental pulp stem cells; WB: western blot; ctr-: negative control.

dehydrated in an ascending series of alcohol rinses and embedded in a glycolmethacrylate resin (Technovit 7200 VLC, Kulzer, Wehrheim, Germany). After polymerization the specimens were sectioned in the mesio-distal direction, with a high-precision diamond disc at about $150 \mu \mathrm{m}$ and grounded down to about $30 \mu \mathrm{m}$ with a specifically designed grinding machine. A total of 2 slides were obtained for each specimen. For general morphologic observations, sections were stained with acid fuchsin and toluidine blue and observed under light microscopy with a Leitz Laborlux (Leitz, Wetzlar, Germany), in order to determine the relative distribution of new bone matrix and absence of dentine. The polarized light were used for distinguish lamellar bone and woven bone.

Histomorphometry was carried out using a light microscope (Laborlux S, Leitz, Wetzlar, Germany) connected to a high resolution video camera (3CCD, JVC KY-F55B, JVC ${ }^{\circledR}$, Santa Clara, CA, USA) and interfaced to a monitor and PC (Intel Pentium III 1200 MMX, Intel', Yokohama, Japan). This optical system was associated with a digitizing pad (Matrix Vision GmbH, Oppenweiler, Germany) and a histometry software package with image capturing capabilities (ImagePro Plus 4.5, Media Cybernetics Inc., Immagini and Computer Snc Milan, Italy). Evaluation of the percentages of residual biomaterial, new bone formation and marrow spaces was performed in the cranial defects of the four experimental groups. Each section was examined at a minimum of $6 x$ magnification, and the entire area of the section was evaluated. Digital images of each section were acquired and used to trace the areas identified as new bone, residual particle and marrow spaces. Image manipulation software was used to create individual layers of new bone, residual particle and marrow spaces. These layers 
Citation: Annibali S, Quaranta R, Scarano A, Pilloni A, Cicconetti A, et al. (2016) Histomorphometric Evaluation of Bone Regeneration Induced by Biodegradable Scaffolds as Carriers for Dental Pulp Stem Cells in a Rat Model of Calvarial "Critical Size" Defect. J Stem Cell Res Ther 6: 322. doi:10.4172/2157-7633.1000322

Page 5 of 8

were then converted to a binary (black and white) form, and area by percentage of each of the three layers was digitally calculated based on number of pixels using image analysis software.

\section{Statistical analysis}

Differences between groups of treatment were analyzed by oneway analysis of variance (ANOVA) followed by Fisher's Protected Least Significant Difference (PLSD) post-hoc test. A p-value $<0.05$ was considered statistically significant. Statistical analysis was performed using the Stat view software from SAS Institute.

\section{Results}

\section{Percentage of residual biomaterial in cranial defects}

Figure 1 shows the percentage of residual biomaterial in the cranial defects in the four experimental groups. One-way ANOVA showed no significant differences among groups. However, we observed that GDPC alone has higher percentage of residual biomaterial than $B-T C P$ (Figure 2).

\section{Percentage of new bone formation in cranial defects}

The percentage of total bone formation is showed in (Table 2). One-way ANOVA showed a significant effect of the treatment (f-value $=4.168 ; \mathrm{p}$-value $<0.05$ ). Post-hoc analysis showed that the percentage of total bone in $\beta$-TCP group was lower than that of $\beta$-TCP/ DPSC $(p<0.01)$, GDPB $(p<0.01)$, and GDPB/DPSC $(p<0.05)$. No other statistical differences were observed.

The percentages of new lamellar and woven bone was also measured in the four experimental groups and the results are shown in (Figure 3). One-way ANOVA showed a significant effect of the treatment on the formation of lamellar bone ( $\mathrm{f}$-value $=9.305$; $\mathrm{p}$-value $<0.01$ ). Post-hoc analysis showed that the percentage of lamellar bone in GDPB group was higher than that of GDPB/DPSC $(\mathrm{p}<0.05)$ and $\mathrm{B}-\mathrm{TCP}(\mathrm{p}<0.001)$. Moreover, the percentage of lamellar bone in $B$-TCP/DPSC was significantly higher than that of $B$-TCP alone $(\mathrm{p}<0.001)$ and GDPB/ $\operatorname{DPSC}(\mathrm{p}<0.05)$.

We also found an effect on woven bone formation (f-value $=10.494$; p-value $<0.01)$. However, the results were different to those of lamellar bone. We observed that the percentage of woven bone in GDPB group was lower than that of GDPB/DPSC $(p<0.05)$ and higher than that of B-TCP $(p<0.05)$. Furthermore, GDPB/DPSC group showed higher

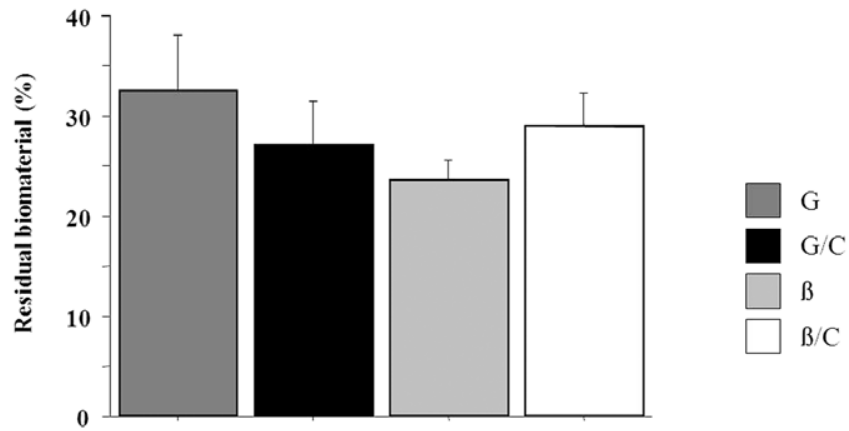

Figure 2: Percentage of residual biomaterial in the cranial defects of the four experimental groups: $ß-T C P(ß) ; ß-T C P / D P S C(B / C) ; G D P B(G)$ and GDPB /DPSC $(\mathrm{G} / \mathrm{C})$. Values are expressed as a percentage of biomaterial on the total area of the defect. Data represent means \pm SEM. ß-TCP: Beta-tricalcium phosphate; GDPB: Granular deproteinized bovine bone; DPSC: Dental pulp stem cells.

\begin{tabular}{|c|c|}
\hline Experimental groups & New bone formation (\%) \\
\hline GDPB $(\mathrm{G})$ & $23.375 \pm 12.3$ \\
\hline GDPB/DPSC $(\mathrm{G} / \mathrm{C})$ & $18.25 \pm 9.22$ \\
\hline B-TCP $(ß)$ & $8.0 \pm 3.46$ \\
\hline ß-TCP/DPSC $($ ß/C) & $22.375 \pm 11.4^{*}$ \\
\hline
\end{tabular}

Data represent means \pm SEM. ß-TCP: Beta-tricalcium phosphate; GDPB Granular deproteinized bovine bone; DPSC: dental pulp stem cells " statistically significant vs $ß-$ TCP $(ß)(p<0.01)$

Table 2: Percentage of total bone (lamellar and woven) formation.

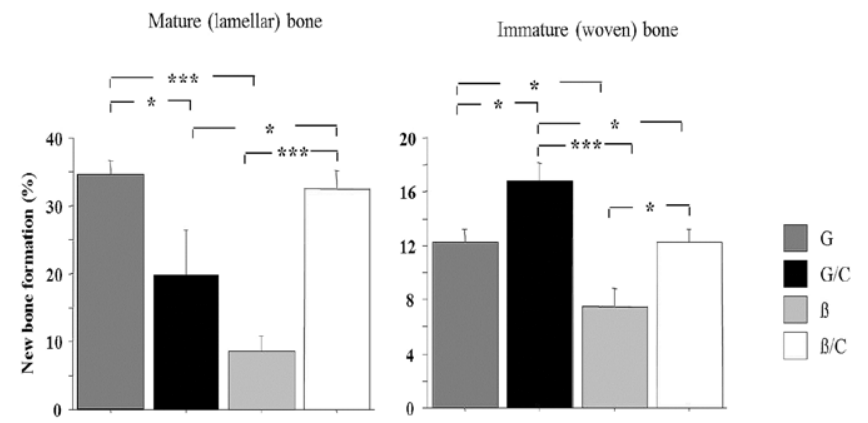

Figure 3: Percentage of new bone (mature and immature) formation in the cranial defects of the four experimental groups: $B-T C P(ß) ; ß-T C P /$ DPSC (B/C); GDPB $(G)$ and GDPB /DPSC $(G / C)$. Values are expressed as a percentage of new bone formation on the total area of the defect. Data represent means \pm SEM. Asterisks indicate significant differences between time groups $\left({ }^{*} p<0.05 ;{ }^{* *} p<0.001\right)$. B-TCP: Beta-tricalcium phosphate; GDPB: Granular deproteinized bovine bone; DPSC: Dental pulp stem cells.

percentage of woven bone as compared to $B$-TCP $(\mathrm{p}<0.001)$ and B-TCP/DPSC $(p<0.05)$ (Figure 3$)$. As for $\beta-T C P$, we found that $\beta-T C P /$ DPSC showed higher percentage of woven formations as compared to $ß$-TCP alone $(\mathrm{p}<0.05)$.

\section{Percentage of marrow spaces in cranial defects}

The percentages of marrow spaces in the cranial defects in the four experimental groups are shown in Figure 4. Also in this case one-way ANOVA showed an overall effect of the treatment (f-value $=5.007$; p-value $<0.05)$. Post-hocs revealed that $B$-TCP had higher percentage of marrow spaces as compared to GDPB $(\mathrm{p}<0.01)$, GDPB/DPSC $(\mathrm{p}<0.01)$ and $B-T C P / D P S C(p<0.05)$. No other statistical differences were observed.

\section{Qualitative observations on histomorphometry}

B-TCP: In general, bone morphology presented differentiated cellular lines specific of mineralized bone, such as osteoblasts, osteocytes but also osteoid and blood vessels. An initial formation of immature bone extending from the periphery of the bone cavities could be seen (Figure 5a,b). The rest of the bone cavity contained fibrous tissue and biomaterial with a mild inflammatory reaction. The inflammatory reaction was characterized by foci of lymphocytes distributed around the periphery of the cavity (Figure $5 b$ ). The tissues present in the defect were composed by $24 \pm 3 \%$ of $B$-TCP particles, $6 \pm 2 \%$ of lamellar bone, $8 \pm 1$ of woven bone and $59 \pm 3 \%$ of marrow spaces.

B-TCP/DPSC: Bone tissue was evident with well differentiated cells and mineralized matrix: osteoid, osteoblasts, osteocytes and blood vessels. Regenerating osseous tissue surrounding some $\beta$-TCP particles and extending from the margin of the axial walls was observed. Bone tissue was positioned in the inter-particular (Figure 6a). New bone extended to the basal third from the margin of the bone defect and 
Citation: Annibali S, Quaranta R, Scarano A, Pilloni A, Cicconetti A, et al. (2016) Histomorphometric Evaluation of Bone Regeneration Induced by Biodegradable Scaffolds as Carriers for Dental Pulp Stem Cells in a Rat Model of Calvarial "Critical Size" Defect. J Stem Cell Res Ther 6: 322. doi:10.4172/2157-7633.1000322

Page 6 of 8

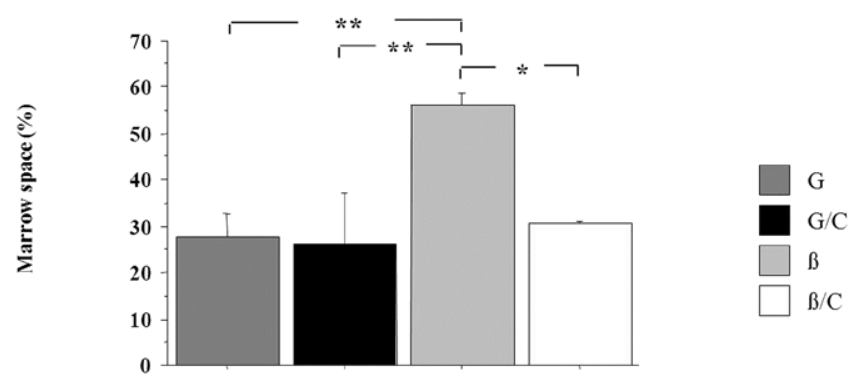

Figure 4: Percentage of marrow space in the cranial defects of the four experimental groups: $ß-T C P(ß) ;$ ß-TCP/DPSC (B/C); GDPB $(G)$ and GDPB/ $\operatorname{DPSC}(\mathrm{G} / \mathrm{C})$. Values are expressed as a percentage of marrow space on the total area of the defect. Data represent means \pm SEM. Asterisks indicate significant differences between time groups $\left({ }^{*} p<0.05 ;{ }^{* *} p<0.01\right)$. B-TCP: Beta-tricalcium phosphate; GDPB: Granular deproteinized bovine bone; DPSC: Dental pulp stem cells.

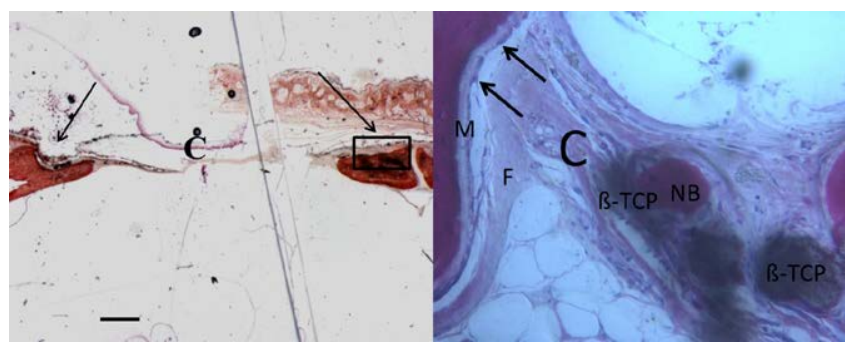

Figure 5: a) no trabecular bone was present in the central portion of the bone defects $(C)$. New bone extended to the basal third from the margin of the bone defect and partially surrounded the $S$ particles (Arrows). Acid fuchsin and toluidine blue $2 X$, Scale bar $=1 \mathrm{~mm}$; b) previous image at higher magnification. Traces of new bone (NB) from the periosteum were seen overlying the superficial portion of the bone defect Osteoblasts,(black arrows) osteocytes but also osteoid $(\mathrm{M})$, and blood vessels were observed. Fibrous tissue $(F)$, inflammatory cells (I), Biomaterial (B-TCP). Acid fuchsin and toluidine blue $100 \mathrm{X}$

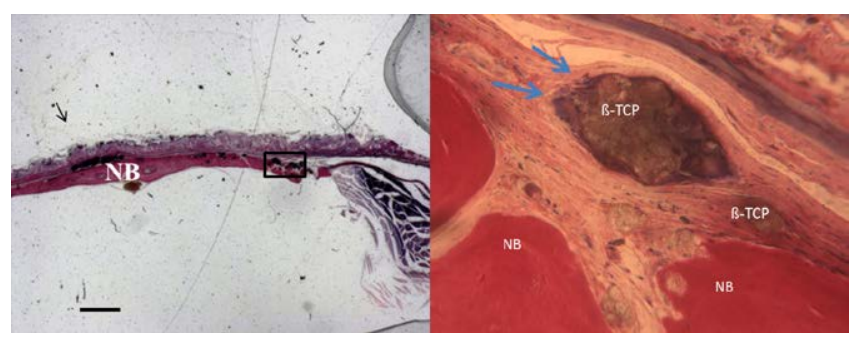

Figure 6: a) new bone was observed surrounding some particles (NB). Bone formation was observed at both margins of the defect, and this was more evident at one of the margins. Acid fuchsin and toluidine blue $2 X$, Scale bar $=1 \mathrm{~mm}$; b) previous image at higher magnification. New bone (NB) surrounded the biomaterial particles (ß-TCP). New bone extended also in central part of the bone defects. Fibrous tissue and biomaterial with a mild multinucleated cells reaction (arrows). Acid fuchsin and toluidine blue 100X

partially surrounded the $ß$-TCP particles. New bone extended also in central part of the bone defects (Figure 6b). Fibrous tissue still occupied little space in the defect area. Traces of new bone from the periosteum were observed, overlying the superficial portion of the bone defect. No dentinal tubules were visible. The tissues present in the defect were composed by $28 \pm 3 \%$ of $B$-TCP/DPSC particles, $32 \pm 2 \%$ of lamellar bone, $12 \pm 1$ of woven bone and $26 \pm 4 \%$ of marrow spaces.
GDPB: Little osteoid matrix was present at the periphery of the bone defects and osteoblasts were observed. Trabecular bone was present in the central portion of the defects (Figure 7a). Particles of biomaterial were mostly surrounded by mature bone and fibrous tissue (Figure 7b). Bone formation was observed at both margins of the defect.Few osteoblasts were present. The tissues present in the defect area were composed by $28 \pm 4 \%$ of GDPB particles, $12 \pm 2 \%$ of lamellar bone, $18 \pm 2$ of woven bone and $28 \pm 4 \%$ of marrow spaces.

GDPB/DPSC: At low magnification, we observed that almost all biomaterial particles were surrounded by mature bone. Osteoid material was found only around some of the particles (Figure 8a). The particles of material were located near the marrow spaces in only a few areas (Figure 8b). In all specimens no inflammatory cell infiltrate was present. No foreign body reactions were present. All particles were clustered and surrounded by newly-formed woven or lamellar bone. Newly-formed bone was always present between the GDPB particles. No epithelial cells or connective tissue were found at the interface. The regenerated bone tissue extended to approximately two-thirds of the bone defect apart from the central and superficial area, where the fibrous tissue still occupied part of the spaces between granules. Prominent lamination of mature bone was observed. Mature bone derived from the endosteal surface filled the external portion of the bone defects (Figure 8b). The periphery and central portion of the cavity showed mineralized new bone formation. No dentinal tubules or predentin were visible. The bone defect was not completely healed and many particles or GDPB were visible. The tissues present in the defect

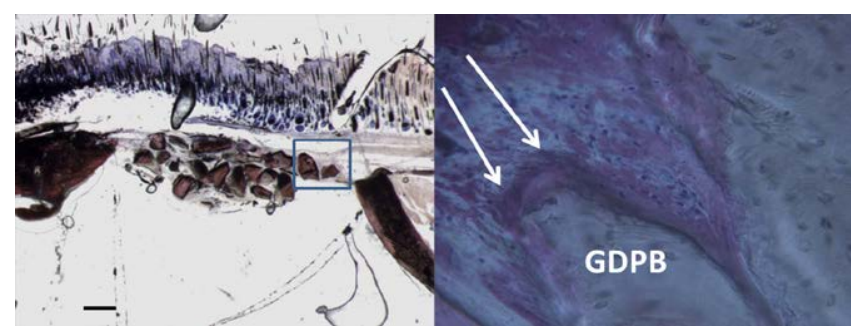

Figure 7: a) the biomaterial particles were mostly surrounded by fibrous tissue. No new bone was present in the central portion of the bone defects. Acid fuchsin and toluidine blue $2 X$, Scale bar=1mm; b) previous image at higher magnification. New bone (Arrows) was present in the periferical portion of the bone defects and around biomaterial particles (GDPB). Acid fuchsin and toluidine blue 100X.

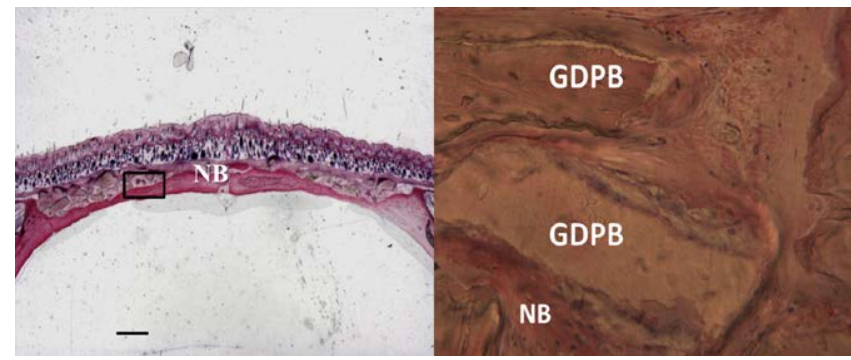

Figure 8: a) new bone (NB) was observed surrounding some particles and extended also in central part of the bone defects. Bone formation was observed at both margins of the defect, and this was more evident at one of the margins. Acid fuchsin and toluidine blue $2 X$, Scale bar $=1 \mathrm{~mm} ;$ b) previous image at higher magnification. New bone (NB) surrounded the biomaterial particles (GDPB). The particles were distributed along the defect and were surrounded by new bone (NB). Acid fuchsin and toluidine blue 100X. 
Citation: Annibali S, Quaranta R, Scarano A, Pilloni A, Cicconetti A, et al. (2016) Histomorphometric Evaluation of Bone Regeneration Induced by Biodegradable Scaffolds as Carriers for Dental Pulp Stem Cells in a Rat Model of Calvarial "Critical Size" Defect. J Stem Cell Res Ther 6: 322. doi:10.4172/2157-7633.1000322

Page 7 of 8

were composed by $31 \pm 4 \%$ of GDPB particles, $36 \pm 2 \%$ of lamellar bone, $14 \pm 1$ of woven bone and $18 \pm 2 \%$ of marrow spaces.

\section{Discussion}

In a previous study we examined bone regeneration induced by dental pulp stem cells (DPSCs) in combination with appropriated scaffolds ( $B-T C P$ and GDPB) in a rat model of calvarial critical defect by using $\mu$ - CT and PET analytical methods [13]. In that study we observed that GDPB implants were mostly well positioned and induced a higher amount of BMD and SUV within the cranial defect as compared to B-TCP. However, the contribution of DPSCs to bone formation in both B-TCP and GDPB-based implants was not clear. Thus, in this study we aimed at further characterize bone regeneration induced by DPSCs in these scaffold-based implants by using histological parameters. We evaluated the percentages of residual biomaterial, new bone formation and marrow space in the cranial defects filled with GDPD- and B-TCPbased implants, alone or in combination with DPSC. Moreover, a qualitative description of the histomorphology of the cranial defect was provided, including the characterization of newly-formed bone, presence ofinflammatory cells infiltrate, and the position of bone formation within the defect.

The results showed that although the percentage of residual biomaterial was similar among experimental groups, the percentage of formation of new bone and marrow space was different. Specifically, we found that, although the percentage of lamellar bone in GDPB group was higher than that of B-TCP, the two scaffolds showed different results when seeded with stem cells. Thus, while GDPB group had higher percentage of lamellar bone than that of GDPB/DPSC, $ß$-TCP alone had lower levels as compared to $B$-TCP/DPSC. When analyzing the woven bone, we found instead that addition of stem cells significantly increased bone formation in both scaffold-based implants, although still higher in GDPB based implants. Another result was that the percentage of marrow spaces was higher in $B$-TCP group as compared to the other groups.

The present findings, when compared to the data obtained with $\mu$ - CT and PET, show that the positive role of GDPD to bone regeneration is due to the formation of mature (lamellar) bone. Moreover, the contribution of stem cells was evident when analyzing the percentage of woven bone, a finding not shown from the previous $\mu$ - CT and PET data. These results confirm previous observations on the comparison between these two scaffolds. Although both of them possess osteoconductive properties and are capable to provide a threedimensional structure for bone regeneration [19-22], the use of GDPB seems to induce a greater percentage of bone formation. GDPB is a biomaterial of natural origin obtained by the deproteinization of bovine bone $[23,24]$ while $B$-TCP is a synthetic bone substitute resembling natural bone in mineral composition [25]. The main difference between the two scaffold is that GDPB has lower level of resorption $[22,24]$ as compared to B-TCP [26] and this property may favor bone formation in the microenvironment of the calvarial defect. However, the present data also suggest that B-TCP may be more efficient when seeded with stem cells as both lamellar and woven bone were increased in the B-TCP/DPSC construct to a level comparable to that of GDPB. Thus, it may be speculated that low resorbability of GDPB may favor the natural process of bone formation, while the high level of resorption of ß-TCP may provide a microenvironment where stem cells are capable to produce osteogenic activity with less interference generated by the interaction with the scaffold, at least in this model. This hypothesis is also confirmed by data showing that B-TCP may show greater osteoconductive and biodegradation properties than GDPB in a rat critical-size defect [13] and by the fact that $B$-TCP alone has a greater percentage of marrow space as compared to GDPB.

Qualitative histomorphometry also showed that addition of stem cells to the scaffolds resulted in greater bone formation in B-TCP/DPSC construct, as evidenced by the presence of bone tissue in the periphery and in the central area of the defect. Most notably, osteogenesis was observed in absence of inflammatory processes which may interfere with the process of regeneration [27]. GDPB scaffolds were also characterized by the presence of bone formation and absence of inflammatory cells infiltrates. However, GDPB alone was characterized by the presence of mature rather than immature bone surrounding the particles of biomaterial. This finding suggests that, although GDPB seems capable to induce greater bone formation as compared to B-TCP alone, this process is likely to terminate earlier as compared to that induced by the addition of DPSC into the construct. Nonetheless, given the low number of animals used in the study, other studies are necessary to validate this hypothesis.

There are some limitation to our data interpretation. Particularly, these data are not in line with the findings reported using other analytical methods such as $\mu$ - CT and PET. The reason for this discrepancy is difficult to explain. Certainly, the different analytical methods may have influenced the data. In the first study we analyzed bone mineral density (BMD) or standard uptake value (SUV) of sodium fluoride tracer $([18 \mathrm{~F}]-\mathrm{NaF})$ incorporation which gave us information on the whole process of bone formation. In this study histology was used instead to differentiate the bone formation between lamellar and woven bone. Thus, it is possible that the difference noted here between the scaffold used alone versus the scaffold seeded with stem cells would not be detectable with $\mu$ - CT and PET methods. On the other hand, it should be noted that $\mu$ - CT and PET methods provide three dimensional data on bone formation while histology can only analyze a section at a two-dimensional level. These different findings suggest that the contribution of stem cells in these types of constructs may be present but only evident on a qualitative level. If the higher percentage of immature bone observed in scaffolds seeded with stem cells is then translated in a superior capacity of inducing bone formation in the clinical practice remains to be determined. Thus, it is advisable that other studies with different combinations of stem cells and scaffolds should be carried out in order to obtain more consisting data between histological and $\mu \mathrm{Ct}$ data.

\section{Conclusion}

This study demonstrates that addition of stem cells significantly increased woven bone formation in both scaffold-based implants. Moreover, these data suggest that in absence of stem cells GDPB, given its natural origin and higher biocompatibility, induces faster and greater lamellar bone formation as compared to that induced by ß-TCP.

\section{Acknowledgement}

This work was supported by "Fondazione Roma" for Biomedical Research.

\section{References}

1. Davies JE, Matta R, Mendes VC, Perri de Carvalho PS (2010) Development, characterization and clinical use of a biodegradable composite scaffold for bone engineering in oro-maxillo-facial surgery. Organogenesis 6: 161-166. [PubMed]

2. Bianco P, Robey PG (2001) Stem cells in tissue engineering. Nature 414: 118121. [PubMed]

3. Chen FM, Sun HH, Lu H, Yu Q (2012) Stem cell-delivery therapeutics for periodontal tissue regeneration. Biomaterials 33: 6320-6344. [PubMed] 
Citation: Annibali S, Quaranta R, Scarano A, Pilloni A, Cicconetti A, et al. (2016) Histomorphometric Evaluation of Bone Regeneration Induced by Biodegradable Scaffolds as Carriers for Dental Pulp Stem Cells in a Rat Model of Calvarial "Critical Size" Defect. J Stem Cell Res Ther 6: 322. doi:10.4172/2157-7633.1000322

Page 8 of 8

4. Mankani MH, Kuznetsov SA, Wolfe RM, Marshall GW, Robey PG (2006) In vivo bone formation by human bone marrow stromal cells: reconstruction of the mouse calvarium and mandible. Stem Cells 24: 2140-2149. [PubMed]

5. Meinel L, Fajardo R, Hofmann S, Langer R, Chen J, et al. (2005) Silk implants for the healing of critical size bone defects. Bone 37: 688-698. [PubMed]

6. Miura M, Miura Y, Sonoyama W, Yamaza T, Gronthos S, et al. (2006) Bone marrow-derived mesenchymal stem cells for regenerative medicine in craniofacial region. Oral Dis 12: 514-522. [PubMed]

7. Yamada Y, Ueda M, Naiki T, Takahashi M, Hata K, et al. (2004) Autogenous injectable bone for regeneration with mesenchymal stem cells and platele rich plasma: tissue-engineered bone regeneration. Tissue Eng 10: 955-964. [PubMed]

8. Mori G, Brunetti G, Oranger A, Carbone C, Ballini A, et al. (2011) Dental pulp stem cells: osteogenic differentiation and gene expression. Ann N Y AcadSci 1237: 47-52. [PubMed]

9. Roberts SJ, Chen Y, Moesen M, Schrooten J, Luyten FP (2011) Enhancement of osteogenic gene expression for the differentiation of human periosteal derived cells. Stem Cell Res 7: 137-144. [PubMed]

10. Annibali S, Cicconetti A, Cristalli P, Giordano G, Trisi P, et al. (2013) A Comparative Morphometric Analysis of Biodegradable Scaffolds as Carriers for Dental Pulp and Periosteal Stem Cells in a Model of Bone Regeneration. J Craniofacial Surg 24: 866-871. [PubMed]

11. Baldini N, De Sanctis M, Ferrari M (2011) Deproteinized bovine bone in periodontal and implant surgery. Dent Mater 27: 61-70. [PubMed]

12. Park JW, Kim JM, Lee HJ, Jeong SH, Suh JY, et al. (2014) Bone healing with oxytocin-loaded microporous $\beta$-TCP bone substitute in ectopic bone formation model and critical-sized osseous defect of rat. J ClinPeriodontol 41: 181-190. [PubMed]

13. Annibali S, Bellavia D, Ottolenghi L, Cicconetti A, Cristalli MP, et al. (2014) Micro-CT and PET analysis of bone regeneration induced by biodegradable scaffolds as carriers for dental pulp stem cells in a rat model of calvarial "critical size" defect: Preliminary data. J Biomed Mater Res B Appl Biomater 102: 815825. [PubMed]

14. Gronthos S, Mankani M, Brahim J, Gehron Robey P, Shi S (2000) Postnatal human dental pulp stem cells (DPSCs) in vitro and in vivo. Proc Natl Acad Sci U S A 97: 13625-13630. [PubMed]

15. Karaöz E, Doğan BN, Aksoy A, Gacar G, Akyüz S et al. (2010) Isolation and in vitro characterization of dental pulp stem cells from natal teeth. Histochem Cell Biol 133: 95-112. [PubMed]
16. Huang CE, Hu FW, Yu CH, Tsai LL, Lee TH, et al. (2014) Concurrentexpression of Oct4 and Nanogmaintainsmesenchymalstem-likeproperty of humandentalpulpcells. Int J MolSci 15: 18623-18639. [PubMed]

17. Mafi P, Hindocha S, Mafi R, Griffin M, Khan WS (2011) Adult mesenchymal stem cells and cell surface characterization - a systematic review of the literature. Open Orthop J 5: 253-260. [PubMed]

18. Mangano C, De Rosa A, Desiderio V, D'Aquino R, Piattelli A et al. (2010) The osteoblastic differentiation of dental pulp stem cells and bone formation on different titanium surface textures. Biomaterials 31: 3543-3551. [PubMed]

19. Kato E, Lemler J, Sakurai K, Yamada M (2014) Biodegradation Property of Beta-Tricalcium Phosphate-Collagen Composite in Accordance with Bone Formation: A Comparative Study with Bio-Oss Collagen $®$ in a Rat Critical-Size Defect Model. Clin Implant Dent Relat Res 16: 202-211. [PubMed]

20. Nguyen LT, Liao S, Chan CK, Ramakrishna S (2012) Enhanced osteogenic differentiation with 3Delectrospunnanofibrous scaffolds. Nanomedicine (Lond) 7: 1561-1575. [PubMed]

21. Sánchez-Salcedo S, Nieto A, Gómez-Barrena E, Vallet-Regí M (2008) Hydroxyapatite/ $\beta$-tricalcium phosphate/agarose macroporous scaffolds for bone tissue engineering. Chem Eng J 137: 62-71.

22. Valentini P, Abensur D (1997) Maxillary sinus floor elevation for implan placement with demineralized freeze-dried bone and bovine bone (Bio-Oss): A clinical study of 20 patients. Int J Periodontics Restorative Dent 17: 232-241. [PubMed]

23. Berglundh T, Lindhe $\mathrm{J}$ (1997) Healing around implants placed in bone defects treated with Bio-Oss. Clin Oral Implants Res 8: 117-124. [PubMed]

24. Piattelli M, Favero GA, Scarano A, Orsini G, Piattelli A (1999) Bone reactions to anorganic bovine bone (Bio-Oss) used in sinus lifting procedure: A histologic long-term report of 20 cases in man. Int J Oral Maxillofac Implants 14: 835-840. [PubMed]

25. LeGeros RZ (2002) Properties of osteoconductive biomaterials: calcium phosphates. ClinOrthopRelat Res 395: 81-98. [PubMed]

26. Borrelli J Jr, Prickett WD, Ricci WM (2003) Treatment of nonunions and osseous defects with bone graft and calcium sulfate. Clin Orthop Relat Res 411: 245-254. [PubMed]

27. Liu Y, Wang L, Kikuiri T, Akiyama K, Chen C, et al. (2011) Mesenchymal stem cell-based tissue regeneration is governed by recipient $\mathrm{T}$ lymphocytes via IFN- $\gamma$ and TNF- $\alpha$. Nat Med 17: 1594-1601. [PubMed]
Citation: Annibali S, Quaranta R, Scarano A, Pilloni A, Cicconetti A, et al. (2016) Histomorphometric Evaluation of Bone Regeneration Induced by Biodegradable Scaffolds as Carriers for Dental Pulp Stem Cells in Rat Model of Calvarial "Critical Size" Defect. J Stem Cell Res Ther 6: 322 doi:10.4172/2157-7633.1000322

\section{OMICS International: Publication Benefits \& Features}

\section{Unique features:}

- Increased global visibility of articles through worldwide distribution and indexing

- Showcasing recent research output in a timely and updated manner

Special issues on the current trends of scientific researche

Special features:

700 Open Access Journals

50,000 editorial team

Rapid review proces

Quality and quick editorial, review and publication processing

Indexing at Pubmed (partial), Scopus, EBSCO, Index Copernicus and Google Scholar etc

- Sharing Option: Social Networking Enabled

- Authors, Reviewers and Editors rewarded with online Scientific Credits

Better discount for your subsequent articles

Submit your manuscript at: http://www.omicsonline.org/submission 